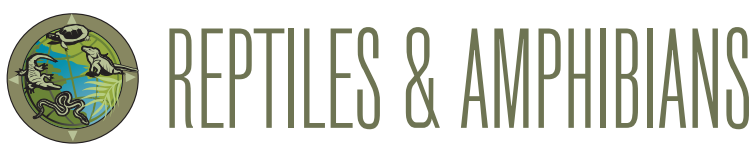

\title{
Predation of a Mesoamerican Cane Toad, Rhinella horribilis (Anura: Bufonidae), by a White-tailed Hawk (Geranoaetus albicaudatus) in Laguna de Tixtla, Guerrero, Mexico
}

\begin{abstract}
Epifanio Blancas-Calva ${ }^{1}$ and Marisol Castro-Torreblanca ${ }^{2,3}$
${ }^{1}$ Instituto de Investigación Científica Área de Ciencias Naturales, Universidad Autónoma de Guerrero, Ciudad Universitaria, Chilpancingo, Guerrero 39087, Mexico (ebcalva@yahoo.com.mx [corresponding author])

${ }^{2}$ Programa de Posgrado en Ciencias Biológicas, Coordinación de Estudios de Posgrado, Universidad Nacional Autónoma de Mexico, Mexico City, Mexico (balam_mampar@hotmail.com)

${ }^{3}$ Unidad de Investigación en Biología Comparada y Biodiversidad, Facultad de Estudios Superiores Zaragoza, Universidad Nacional Autónoma de Mexico, Mexico City, Mexico
\end{abstract}

$T_{a}^{h}$ he White-tailed Hawk (Geranoaetus albicaudatus), a tropical raptor that ranges from southern Texas through Central America to Patagonia in northern Argentina (Heredia and Clark 1984; Ferguson-Lees and Christie 2005; Granzinolli and Motta-Junior 2007), feeds on a wide range of vertebrates and invertebrates (Cottam and Knappen 1939; Stevenson and Meitzen 1946; Granzinolli and Motta-Junior 2007). White-tailed Hawks typically sight prey while gliding or in stationary flight some $15-50 \mathrm{~m}$ above the ground (Oberholser 1974) in open fields with scattered trees and bushes or brushy ranchland (Howell and Webb 2005).

During a study of water birds at the endorheic Laguna de Tixtla, Guerrero, México (17³3’48.30”N, 99²3’11.25”W; elev. 1,337 $\mathrm{m}$ asl), at about $1645 \mathrm{~h}$ on 23 January 2021, we observed a White-tailed Hawk preying on an adult Mesoamerican Cane Toad (Rhinella horribilis). While gliding just above the lake, which was covered by Common Water Hyacinths (Eichhornia crassipes), it suddenly descended and captured the toad (Fig. 1) before flying south into an area covered by dry forest vegetation.

During a year of fieldwork in this area, we recorded a White-tailed Hawk four times and, on three different occasions, observed predation on Mesoamerican Cane Toads, although these amphibians are toxic to some predatory birds that avoid ingesting them (Beckmann et al. 2011). The Laguna of Tixtla is a natural, ephemeral, eutrophicated body of water surrounded by agricultural fields and bordered to the west by the city of Tixtla, which discharges the wastewater that is largely responsible for the eutrophication (CastroTorreblanca and Blancas-Calva 2021).

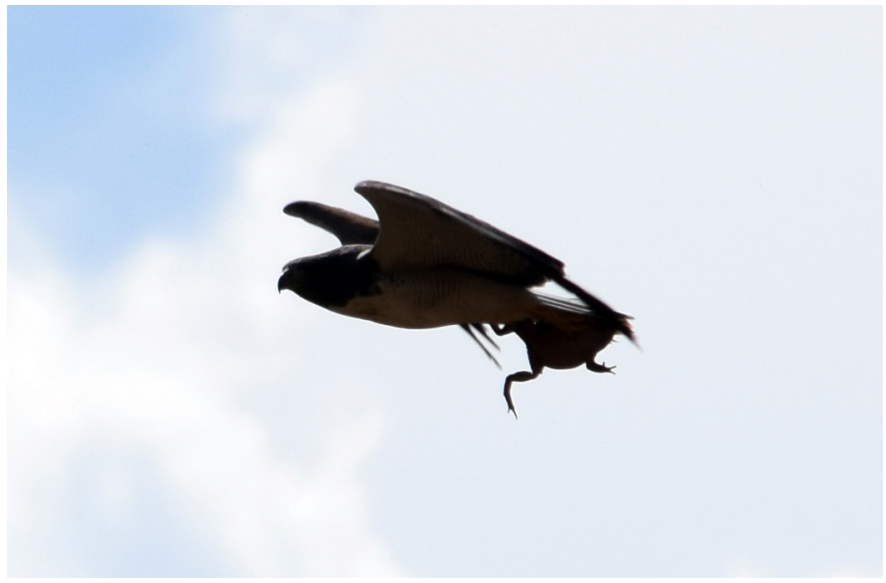

Fig. 1. A White-tailed Hawk (Geranoaetus albicaudatus) in flight after preying on a Mesoamerican Cane Toad (Rhinella horribilis). Photograph by Epifanio Blancas-Calva.

\section{Acknowledgments}

We thank J.C. Blancas-Hernández for reviewing an earlier draft of this manuscript and G. Santos-Barrera for helpful corrections to the English version.

\section{Literature Cited}

Beckmann, C., M.R. Crossland, and R. Shine. 2011. Responses of Australian wading birds to a novel toxic prey type, the invasive cane toad Rhinella marina. Biological Invasions 13: 2925-2934. https://doi 10.1007/s10530-011-9974-1.

Castro-Torreblanca, M. and E. Blancas-Calva. 2021. Anophthalmia in a juvenile Pine Toad, Incilius occidentalis (Anura: Bufonidae), from Laguna de Tixtla, Guerrero, Mexico. Reptiles \& Amphibians 28: 22-23. https://doi. org/10.17161/randa.v28i1.

Cottam, C. and P. Knappen. 1939. Food of some uncommon North American birds. The Auk 56: 138-169. https://doi.org.10.2307/4078038. 
Ferguson-Lees, J. and D.A. Christie. 2005. Raptors of the World. Princeton University Press, Princeton, New Jersey, USA.

Granzinolli, M.A.M. and J.C. Motta-Junior. 2007. Feeding ecology of the Whitetailed Hawk (Buteo albicaudatus) in south-eastern Brazil. Emu 107: 214-222. https://doi.org/10.1071/MU06045.

Heredia, B. and W.S. Clark. 1984. Kleptoparasitism by White-Tailed Hawk (Buteo albicaudatus) on Black-Shouldered Kite (Elanus caeruleus leucurus) in southern
Texas. Raptor Research 18: 30-31. https://doi.org/10.1071/mu06045.

Howell, S.N.G. and S. Webb. 2005. A Guide to the Birds of Mexico and Northern Central America. Oxford University Press Inc., New York, New York, USA.

Oberholser, H.C. 1974. The Bird Life of Texas. Volume 1. University of Texas Press, Austin, Texas, USA.

Stevenson, J.O. and L.H. Meitzen. 1946. Behavior and food habits of Sennett's White-tailed Hawk in Texas. Wilson Bulletin 58: 198-205. 